\title{
PENGARUH MARKETING MIX TERHADAP IMPULSE BUYING DENGAN NICHE MARKET SEBAGAI MODERASI PADA INDUSTRI JASA PENDIDIKAN
}

\author{
Pranakusuma Sudhana ${ }^{1)}$, Lukmandono ${ }^{2)}$, Rony Prabowo ${ }^{3)}$ \\ ${ }^{1), 2), 3)}$ Magister Teknik Industri, Institut Teknologi Adhi Tama Surabaya
}

\begin{abstract}
Abstrak . Pendidikan merupakan suatu industri jasa yang cukup penting, namun tidak banyak diteliti. Sebagai penyedia jasa, perguruan tinggi perlu melakukan berbagai usaha untuk dapat bersaing, salah satunya adalah marketing mix. Penelitian ini bertujuan untuk menguji hipotesis bahwa variabel-variabel 7P marketing mix secara bersama-sama berpengaruh positif dan signifikan terhadap impulse buying yang telah banyak mendukung penjualan barang dengan dimoderasi oleh keunikan suatu program studi yang diistilahkan dengan niche market. Hasil analisis data menggunakan metode SEM terhadap responden siswa-siswi SMA yang telah menghadiri pameran pendidikan menyimpulkan bahwa hipotesis tersebut ditolak. Karena keputusan untuk memilih suatu program studi bukan merupakan proses yang mudah untuk dipahami dan tidak dapat terjadi secara tiba-tiba (impulsif), perguruan tinggi disarankan untuk melakukan usaha-usaha lain yang bersifat konstan dalam upaya menarik minat dan meyakinkan calon mahasiswa (prospek).
\end{abstract}

Kata Kunci: Marketing Mix, Impulse Buying, Niche Market, Jasa, Pendidikan.

Pendidikan merupakan suatu industri jasa yang cukup penting. Pada beberapa negara maju seperti Amerika dan Singapura, industri tersebut berkontribusi sekitar 10\% terhadap Produk Domestik Bruto (PDB), terbesar kedua setelah sektor kesehatan [1]. Sementara itu di Indonesia, sektor jasa secara umum berkontribusi sekitar 60\% terhadap PDB dengan pertumbuhan mencapai double digit [2]. Selain penting bagi perekonomian suatu negara, pendidikan juga menentukan kemajuan atau perkembangan negara tersebut [3]. Dengan posisi yang demikian penting, tidak banyak penelitian yang dilakukan pada sektor ini apabila dibandingkan dengan sektor-sektor jasa lainnya seperti keuangan, komunikasi, transportasi dan logistik [1].

Sebagai perusahaan penyedia jasa pada sektor pendidikan, perguruan tinggi menghadapi berbagai tantangan termasuk dalam bentuk kompetisi yang semakin meningkat baik pada tingkat lokal, nasional, regional sampai global setidaknya selama dua dekade terakhir [4]. Di Indonesia, pertumbuhan jumlah perguruan tinggi ternyata juga sangat pesat di mana saat ini terdapat sekitar 4.500 perguruan tinggi. Fenomenafenomena tersebut menunjukkan bahwa pendidikan tinggi telah ditempatkan sebagai sebuah komoditas pasar [5]. Dalam situasi yang demikian kompetitif, untuk memperbaiki dan meningkatkan keberadaannya, sebuah perguruan tinggi perlu melakukan usaha-usaha pemasaran dan salah satu alat pemasaran yang digunakan untuk mempengaruhi keputusan membeli adalah bauran pemasaran atau dikenal sebagai marketing mix [6], di mana untuk bidang jasa terdiri dari 7P yaitu product, price, place, promotion, people, process dan physical evidence.

Usaha-usaha marketing mix perlu diarahkan sehingga dapat menimbulkan marketing stimuli (dorongan pemasaran), dimana salah satu hasilnya adalah fenomena impulse buying atau pembelian yang tidak terencana [7]. Fenomena tersebut biasanya terjadi pada penjualan barang secara retail, namun tidak selalu demikian [8]. Sehingga dapat disimpulkan bahwa fenomena tersebut dapat juga terjadi pada sektor jasa. Sebuah tinjauan literatur yang komprehensif mengenai impulse buying dalam kurun waktu 60 tahun terakhir (mulai dari tahun 1950 sampai tahun 2011) tidak menemukan adanya penelitian yang dilakukan pada sektor jasa apalagi jasa pendidikan meskipun fenomena tersebut telah menyebabkan sejumlah besar barang terjual setiap tahunnya [9]. 
Terjadinya fenomena impulse buying salah satunya dipengaruhi oleh karakteristik suatu produk [10]. Terkait dengan marketing mix, maka product merupakan program studi (prodi) yang perlu dirancang sesuai dengan kebutuhan dan keinginan pasar serta didiferensiasi dengan memiliki keunikan tertentu (niche market) sehingga menimbulkan dorongan untuk membeli. Melakukan penelitian mendalam mengenai impulse buying akan meningkatkan keunggulan bersaing [10]. Berdasarkan uraian sebelumnya, maka penelitian ini mempunyai tujuan untuk menguji hipotesis bahwa variabel-variabel marketing mix secara bersama berpengaruh positif dan signifikan terhadap terjadinya impulse buying dengan niche market sebagai moderasi saat calon mahasiswa akan membeli jasa pendidikan tinggi.

Penelitian ini berjenis eksplanatori dengan pendekatan kuantitatif. Kuesioner digunakan untuk memperoleh data primer dan mempunyai lima skala likert yaitu $1=$ sangat tidak setuju, 2 = tidak setuju, 3 = ragu-ragu, 4 $=$ setuju dan $5=$ sangat setuju. Karena keterbatasan biaya dan waktu, penelitian dilakukan dengan metode purposive sampling dimana sampel dalam penelitian ini adalah siswa-siswi Sekolah Menengah Atas (SMA) pada beberapa kota di Jawa Timur yaitu Surabaya, Sidoarjo, Malang, Kediri, Jember dan Banyuwangi yang telah menghadiri pameran pendidikan tinggi di sekolah masingmasing. Calon responden diundang menggunakan email untuk mengisi kuesioner online yang telah dipersiapkan sebelumnya pada Google Form. Pengumpulan data dilaksanakan mulai bulan Oktober sampai Desember 2017. Dalam penelitian ini jumlah populasinya tidak diketahui dengan pasti, sehingga jumlah sampel dihitung menggunakan rumus Lemeshow:

$$
\mathrm{n}=\frac{\mathrm{Z}^{2}}{4(\text { Moe })^{2}}
$$

dimana:

$\mathrm{n}=$ jumlah sampel; $\mathrm{Z}=1,96$ dimana merupakan nilai dari tabel distribusi normal dengan tingkat keyakinan 95\% dan Moe = $10 \%$ atau 0,1 dimana merupakan Margin of Error atau tingkat kesalahan maksimum yang dapat ditoleransi dimana biasanya $10 \%$ atau
0,1 . Berdasarkan perhitungan dengan rumus tersebut, didapatkan jumlah sampel adalah sebanyak 96,04 yang dibulatkan menjadi 100 orang.

\section{METODE}

Metode analisis kuantitatif yang biasa digunakan di antaranya adalah regresi, korelasi, factor analysis, cluster analysis dan teknik statistik multivariate lainnya bisa disebut metode analisis generasi pertama. Apabila metode-metode generasi pertama dipaksakan untuk digunakan maka akan dihasilkan pengukuran dengan tingkat kesalahan (error) yang besar [11]. Sehingga diperlukan metode yang mampu menganalisis hubungan antar variabel dimana dikenal dengan Structural Equation Modeling (SEM). Sejak kemunculannya, SEM yang dikenal merupakan covariance based atau CB-SEM. Karena banyaknya syarat yang menghambat penggunaannya, muncul metode SEM alternatif yang dikenal dengan variance based atau VB-SEM dan disebut sebagai Partial Least Square (PLS) [11]. Metode VB-SEM atau PLS dapat diterapkan pada semua skala data, tidak membutuhkan banyak asumsi seperti normalitas data, ukuran sampel tidak harus besar, dapat digunakan untuk mengkonfirmasi teori yang telah ada maupun untuk membangun hubungan yang belum ada landasan teorinya serta permodelan strukural dapat bersifat reflektif maupun formatif [12]. Software yang dapat dipakai untuk melakukan analisis adalah SmartPLS dimana dalam penelitian ini digunakan versi 3.2.7.

Penelitian ini mempunyai model persamaan struktural seperti nampak pada Gambar 1. Terdapat tujuh variabel laten eksogen yaitu 7P marketing mix, satu variabel laten moderasi yaitu niche market dan satu variabel laten endogen yaitu impulse buying. Pada software SmartPLS, efek moderasi dapat diamati dengan membuat variabel tersendiri yang merupakan perkalian antara variabel laten moderasi dan eksogen. Masing-masing variabel laten mempunyai tiga indikator dengan definisi operasional sebagai berikut: (1) Variabel laten eksogen yaitu Product dengan indikator X11 (terdapat prodi yang sesuai dengan kebutuhan dan keinginan calon mahasiswa), X12 (terdapat informasi kegiatankegiatan ekstra di luar perkuliahan, X13 (terdapat prodi yang memberikan prospek karir 
bagus di masa datang); Price dengan indikator X21 (terdapat uang kuliah yang sesuai dengan kemauan dan kemampuan), X22 (terdapat penawaran diskon atau beasiswa), X23 (terdapat pilihan cara pembayaran); Place dengan indikator X31 (terdapat fisik stan pameran beserta isinya yang menarik), X32 (terdapat ruang yang lega dan suasana yang nyaman untuk berkonsultasi), X33 (terdapat stan pameran yang mudah dilihat atau ditemukan oleh pengunjung pameran); Promotion dengan indikator X41 (terdapat rekomendasi atau word of mouth yang baik, X42 (terdapat informasi produk pendidikan yang jelas oleh Sales Executive), X43 (terdapat berbagai iklan di berbagai media); People dengan indikator X51 (terdapat kehadiran dosen yang terkenal), X52 (terdapat Sales Executive yang trampil dalam menjelaskan informasi prodi), X53 (terdapat sikap dan cara berpakaian yang baik dari perwakilan perguruan tinggi yang ada di stan pameran); Process dengan indikator X61 (terdapat interaksi dan komunikasi yang baik antara
Sales Executive dan pengunjung), X62 (terdapat presentasi program studi yang menarik), X63 (terdapat aktivitas pasca pameran yang dilakukan oleh Sales Executive); Physical evidence dengan indikator X71 (terdapat prospektus, brosur, CD-ROM, bahan ajar dan buku-buku yang digunakan dalam perkuliahan), X72 (terdapat berbagai suvenir menarik yang dapat dibawa pulang), X73 (terdapat komputer atau laptop dengan fitur multimedia dan Pendaftaran Online); (2) Variabel laten moderasi yaitu Niche Market dengan indikator Y11 (prodi yang unik), Y12 (prodi jarang ada di perguruan tinggi lain), Y13 (prodi yang jarang diketahui); (3) Variabel laten endogen yaitu Impulse buying dengan indikator Y21 (mendaftar saat itu juga dan di tempat itu juga meskipun tanpa direncanakan sebelumnya), Y22 (mendaftar saat itu juga dan di tempat itu juga tanpa memikirkan akibat dari keputusan tersebut di kemudian hari), Y23 (mendaftar saat itu juga dan di tempat itu juga setelah mengalami berbagai dorongan (stimuli).

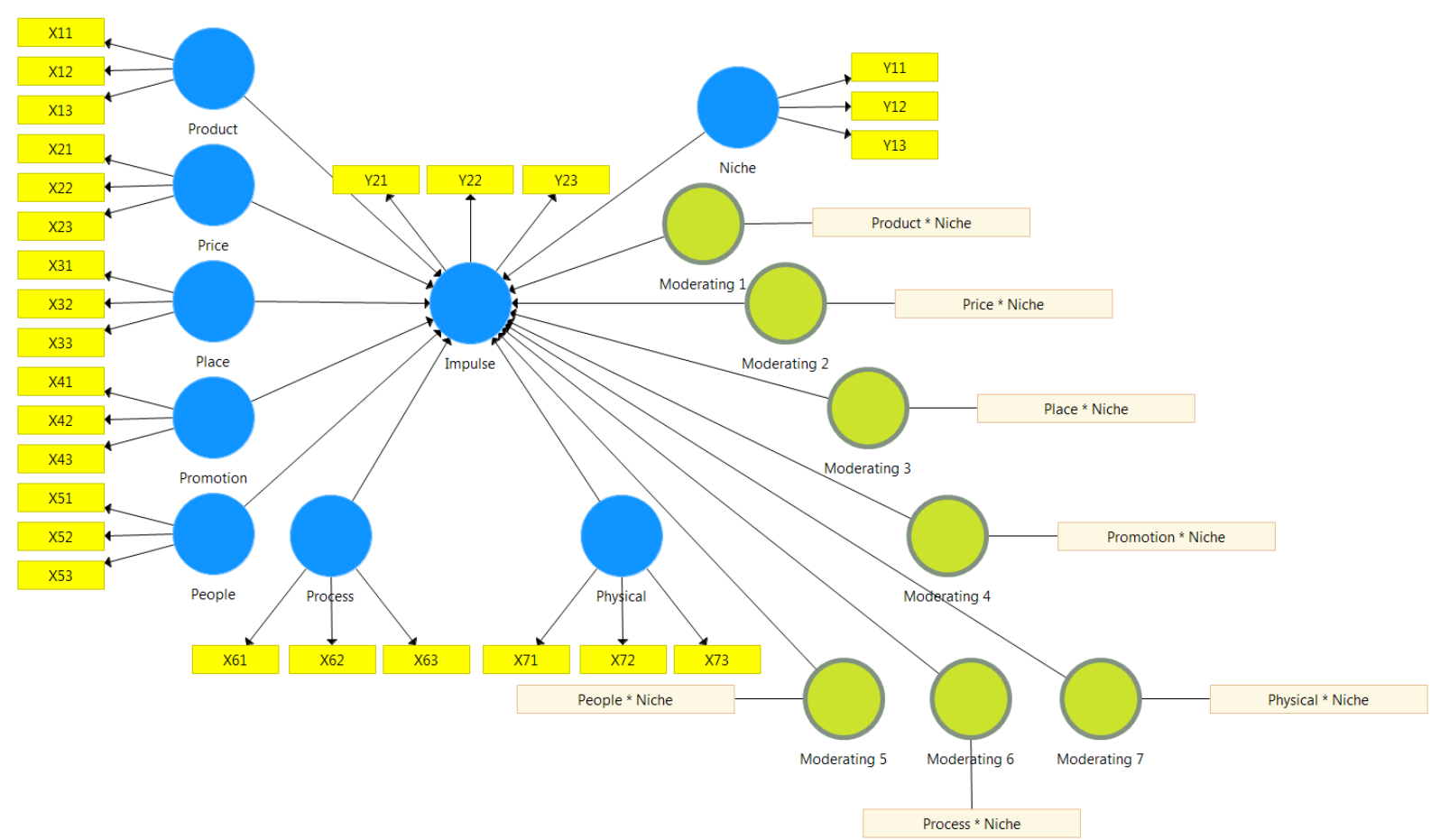

Gambar 1. Model Penelitian Pengaruh Marketing Mix Terhadap Impulse Buying

Pengujian validitas data dilakukan dengan mengkalkulasi model dan dilanjutkan dengan melihat beberapa parameter goodness of fit. Untuk outer model: (1) convergent validity, dimana tiap indikator harus mempunyai output loading $\geq 0,5 ;$ (2) discriminant validity, dimana tiap variabel laten harus mempunyai Average Variance Extracted (AVE) $\geq 0,5$ dan (3) composite reliability, dimana tiap variabel laten harus mempunyai output $\geq 0,7$. Untuk inner model digunakan R-square dari variabel laten dengan 
interpretasi yang sama dengan regresi. Sedangkan pengujian reliabilitas data dilakukan menggunakan Cronbach's Alpha dengan nilai harapan $>0,7$. Setelah semua parameter kelayakan data dipenuhi, maka selanjutnya dilakukan bootstraping. Hubungan antar variabel harus menghasilkan nilai t-stat > 1,96 (signifikan 0,05 ) untuk bisa dinyatakan bahwa terjadi hubungan yang signifikan.

\section{HASIL DAN PEMBAHASAN}

Bagian ini menyajikan hasil analisis data menggunakan software SmartPLS beserta pembahasannya.

\section{Kalkulasi Model}

Tabel 1 merinci goodness of fit dari outer model. Nampak pada tabel tersebut bahwa 1) semua indikator mempunyai output loading $\geq$ 0,5 (syarat convergent validity), 2) semua variabel laten mempunyai $\mathrm{AVE} \geq 0,5$ (syarat discriminant validity) dan 3) semua variabel laten mempunyai composite reliability $\geq 0,7$. Dengan demikian dapat disimpulkan semua syarat validitas terpenuhi. Sementara itu, berdasarkan nilai-nilai Cronbach's Alpha-nya, terdapat konsistensi jawaban responden pada setiap variabel latennya sehingga nilainya melebihi nilai harapan atau > 0,7 dan dapat disimpulkan bahwa variabel-variabel tersebut reliabel. Dengan demikian variabel-variabel product, price, place, promotion, people, process, physical evidence, niche market dan impulse buying adalah valid dan reliabel untuk menguji hipotesis.

Tabel 1. Hasil Kalkulasi Model

\begin{tabular}{|c|c|c|c|c|c|}
\hline Indikator & $\begin{array}{c}\text { Convergent } \\
\text { Validity }\end{array}$ & $\begin{array}{l}\text { Variabel } \\
\text { Laten }\end{array}$ & $\begin{array}{l}\text { Discriminant } \\
\text { Validity }\end{array}$ & $\begin{array}{l}\text { Composite } \\
\text { Reliability }\end{array}$ & $\begin{array}{c}\text { Cronbach's } \\
\text { Alpha }\end{array}$ \\
\hline $\mathrm{X} 11$ & 0,838 & \multirow{3}{*}{ Product } & \multirow{3}{*}{0,741} & \multirow{3}{*}{0,896} & \multirow{3}{*}{0,826} \\
\hline $\mathrm{X} 12$ & 0,867 & & & & \\
\hline $\mathrm{X} 13$ & 0,876 & & & & \\
\hline $\mathrm{X} 21$ & 0,803 & \multirow{3}{*}{ Price } & \multirow{3}{*}{0,714} & \multirow{3}{*}{0,882} & \multirow{3}{*}{0,805} \\
\hline $\mathrm{X} 22$ & 0,850 & & & & \\
\hline $\mathrm{X} 23$ & 0,881 & & & & \\
\hline X31 & 0,832 & \multirow{3}{*}{ Place } & \multirow{3}{*}{0,699} & \multirow{3}{*}{0,874} & \multirow{3}{*}{0,811} \\
\hline X32 & 0,793 & & & & \\
\hline X33 & 0,881 & & & & \\
\hline $\mathrm{X} 41$ & 0,856 & \multirow{3}{*}{ Promotion } & \multirow{3}{*}{0,742} & \multirow{3}{*}{0,896} & \multirow{3}{*}{0,835} \\
\hline $\mathrm{X} 42$ & 0,847 & & & & \\
\hline $\mathrm{X} 43$ & 0,881 & & & & \\
\hline $\mathrm{X} 51$ & 0,799 & \multirow{3}{*}{ People } & \multirow{3}{*}{0,740} & \multirow{3}{*}{0,895} & \multirow{3}{*}{0,823} \\
\hline X52 & 0,879 & & & & \\
\hline X53 & 0,900 & & & & \\
\hline X61 & 0,924 & \multirow{3}{*}{ Process } & \multirow{3}{*}{0,823} & \multirow{3}{*}{0,933} & \multirow{3}{*}{0,892} \\
\hline X62 & 0,928 & & & & \\
\hline X63 & 0,869 & & & & \\
\hline X71 & 0,954 & \multirow{3}{*}{$\begin{array}{l}\text { Physical } \\
\text { Evidence }\end{array}$} & \multirow{3}{*}{0,814} & \multirow{3}{*}{0,929} & \multirow{3}{*}{0,900} \\
\hline $\mathrm{X} 72$ & 0,840 & & & & \\
\hline X73 & 0,909 & & & & \\
\hline Y11 & 0,900 & \multirow{3}{*}{$\begin{array}{l}\text { Niche } \\
\text { Market }\end{array}$} & \multirow{3}{*}{0,667} & \multirow{3}{*}{0,859} & \multirow{3}{*}{0,761} \\
\hline Y12 & 0,898 & & & & \\
\hline Y13 & 0,640 & & & & \\
\hline Y21 & 0,871 & & & & \\
\hline $\mathrm{Y} 22$ & 0,869 & Impulse & 0,681 & 0,864 & 0,762 \\
\hline Y23 & 0,729 & & & & \\
\hline
\end{tabular}

Nilai R Square dan adjusted R Square Impulse Buying yang masing-masing adalah 0,356 dan 0,241 menunjukkan bahwa variabel- variabel 7P marketing mix dengan moderasi niche market hanya berpengaruh sekitar 25\% sampai $35 \%$ saja selebihnya terdapat faktor- 
faktor lain di luar model. Dengan demikian, korelasi antara marketing mix dan terjadinya impulse buying adalah lemah.
Dikarenakan semua parameter kelayakan data terpenuhi, maka selanjutnya dilakukan bootstraping. Tabel 2 merinci hasil dari proses tersebut.

\section{Bootstraping Model}

Tabel 2. Hasil Bootstraping Model

\begin{tabular}{|c|c|c|c|c|c|}
\hline Hubungan antar variabel & $\begin{array}{c}\text { t-stat } \\
\text { bersama }\end{array}$ & $\begin{array}{l}\text { t-stat } \\
\text { parsial }\end{array}$ & $\begin{array}{c}\text { t-stat } \\
\text { parsial saat } \\
\text { dimoderasi }\end{array}$ & $\begin{array}{c}\text { t-stat } \\
\text { Niche } \\
\text { (moderator) }\end{array}$ & $\begin{array}{c}\text { t-stat } \\
\text { efek } \\
\text { moderasi }\end{array}$ \\
\hline Product $\rightarrow$ Impulse & 0,55 & 4,62 & 2,45 & 2,81 & 2,33 \\
\hline Price $\rightarrow$ Impulse & 0,16 & 4,38 & 2,49 & 3,54 & 2,98 \\
\hline Place $\rightarrow$ Impulse & 1,22 & 6,73 & 2,94 & 2,54 & 1,09 \\
\hline Promotion $\rightarrow$ Impulse & 1,05 & 6,57 & 3,17 & 2,65 & 1,64 \\
\hline People $\rightarrow$ Impulse & 1,45 & 6,13 & 4,15 & 2,16 & 2,60 \\
\hline Process $\rightarrow$ Impulse & 0,99 & 3,17 & 1,70 & 3,06 & 2,51 \\
\hline Physical $\rightarrow$ Impulse & 0,86 & 2,58 & 1,29 & 3,57 & 1,58 \\
\hline Niche Market $\rightarrow$ Impulse & 1,71 & & & & \\
\hline Product $*$ Niche $\rightarrow$ Impulse & 0,64 & & & & \\
\hline Price $*$ Niche $\rightarrow$ Impulse & 0,99 & & & & \\
\hline Place $*$ Niche $\rightarrow$ Impulse & 0,41 & & & & \\
\hline Promotion $*$ Niche $\rightarrow$ Impulse & 1,05 & & & & \\
\hline People $*$ Niche $\rightarrow$ Impulse & 0,42 & & & & \\
\hline Process $*$ Niche $\rightarrow$ Impulse & 1,34 & & & & \\
\hline Physical $*$ Niche $\rightarrow$ Impulse & 0,39 & & & & \\
\hline
\end{tabular}

Dari hasil analisis hubungan antar variabel di atas, dapat disimpulkan bahwa $7 \mathrm{P}$ marketing mix secara bersama-sama tidak berpengaruh dalam memicu terjadinya impulse buying pada saat calon mahasiswa akan membeli jasa pendidikan tinggi pada acara pameran dengan dimoderasi oleh keunikan prodi (semua t-stat bersama < 1,96). Hasil tersebut mengkonfirmasi penelitian sebelumnya yang menyimpulkan bahwa secara bersama-sama tidak semua variabel marketing mix berpengaruh secara signifikan terhadap minat beli jasa pendidikan tinggi, bahkan terdapat variabel-variabel yang tidak berpengaruh sama sekali [7], [13]. Niche market hanya merupakan sebuah potential moderator. Gambar 2 menunjukkan proporsi siswa-siswi SMA yang menjawab bahwa mereka akan mengambil keputusan secara impulsif dalam memilih suatu program studi pada sebuah perguruan tinggi.

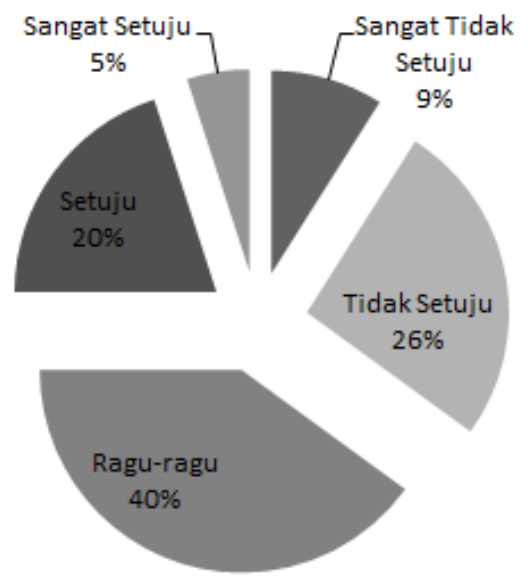

Gambar 2. Proporsi Pengambilan Keputusan Impulsif 
Nampak pada gambar di atas bahwa $35 \%$ responden menjawab tidak setuju atau sangat tidak setuju. Sementara itu, porsi terbesar sebanyak $40 \%$ adalah mereka yang menyatakan ragu-ragu. Pemahaman proses pengambilan keputusan oleh siswa-siswi SMA memang cukup sulit dilakukan dikarenakan banyaknya faktor yang terjadi secara bersamaan mempengaruhi proses tersebut [14]. Secara parsial (individual) masing-masing variabel 7P marketing mix memang berpengaruh positif dan signifikan terhadap impulse buying. Namun, dengan moderasi niche market, pengaruh itu menjadi jauh lebih kecil. Niche market menjadi quasi moderator (t-stat moderator dan efek moderasinya signifikan) pada variabel product, price, people, process dan menjadi predictor moderator (t-stat moderator signifikan, t-stat efek moderasinya tidak) pada variabel place, promotion dan physical. Variabel 7P marketing mix seharusnya digunakan secara bersama, misalnya product tidak mungkin tanpa price, sehingga impulse buying memang sulit terjadi. Untuk memahami proses pengambilan keputusan oleh siswa-siswi SMA dibutuhkan pendekatan multi-disiplin, bukan hanya pendekatan bisnis saja namun juga sosial, ekonomi dan pendidikan karena proses tersebut dipandang sebagai investasi dimana ada harapan bahwa pendapatan finansial dan status sosial mereka akan meningkat di masa datang [14].

\section{KESIMPULAN DAN SARAN Kesimpulan}

Proses pengambilan keputusan untuk memilih suatu prodi pada sebuah perguruan tinggi bukan merupakan proses yang mudah untuk dipahami dan tidak terjadi secara tibatiba (impulsif). Diperlukan waktu untuk mencari prodi yang sesuai untuk kemudian dipertimbangkan dan diputuskan. Karenanya perguruan tinggi disarankan untuk melakukan usaha-usaha selain marketing mix yang sifatnya konstan, terus menerus misalnya pelatihan, seminar dan open house, dalam upaya menarik minat dan meyakinkan calon konsumen (prospek). Untuk penelitian berikutnya, disarankan menemukan kombinasi dari variabel-variabel 7P marketing mix yang dapat berpengaruh secara positif dan signifikan terhadap impulse buying.

\section{DAFTAR PUSTAKA}

[1]. Larson, 2009. "Education: Our Most Important Service Sector". Service Science, 1(4), i-iii.

[2]. Syukro, 2016. "Sudah Saatnya Indonesia Fokus di Sektor Jasa". Beritasatu.com edisi 8 Maret 2016.

[3]. Hakim et al., 2014. "Sistem Pengukur Kualitas Layanan Pendidikan Menggunakan Educational Quality". Jurnal Pendidikan Teknologi Informasi, 7(1).

[4]. Dado et al., 2013. "Linking Service Quality and Satisfaction to Behavioural Intentions in Higher Education Setting", Ekonomicky, 61(6), 578-596.

[5]. Wardiah, I., Indrasary, Y., 2016. "Analisis Pengukuran Performa Layanan Pendidikan Dengan Metode Eduqual Berdasarkan Perbedaan Ekspektasi dan Persepsi Mahasiswa Serti Kontribusinya Terhadap Loyalitas dan Motivasi Belajar Mahasiswa, Prosiding Seminar Nasional Riset Terapan 2016, E9-E20.

[6]. Enache, 2011. "Marketing Higher Education Using The 7Ps Framework", Bulletin of the Transilvania University of Brasov, 4(53), 23-30.

[7]. Margaretha, 2011. "Analisis Pengaruh Bauran Pemasaran Jasa Terhadap Minat Beli Pada Program Magister Manajemen Universitas Kristen Maranatha", Prosiding Seminar Nasional Teknologi Informasi \& Komunikasi Terapan 2011.

[8]. Kollat dan Willet, 1969. "Is Impulse Purchasing Really a Usefull Concept for Marketing Decisions?", Journal of Marketing, 33, 79-83.

[9]. Muruganantham dan Bhakat, 2013. "A Review of Impulse Buying Behavior", International Journal of Marketing Studies, 5(3), 149-160.

[10]. Tinne, 2010. "Impulse Purchasing: A Literatur Overview", ASA University Review, 4(2), 66-73.

[11]. Kurniawan, 2011. "Partial Least Square (PLS) Sebagai Metode Alternatif SEM Berbasis Varians (Lisrel) Dalam Eksplorasi Data Survey dan Data Mining", Jurnal Telematika, 7(1).

[12]. Jaya, I.N.M., Sumertajaya, I.M., 2008. "Pemodelan Persamaan Struktural 
Dengan Partial Least Square", Prosiding Semnas Matematika dan Pendidikan Matematika 2008.

[13]. Muhyidin, U., 2015. "Pengaruh Bauran Pemasaran Jasa Pendidikan Terhadap Keputusan Mahasiswa Memilih Perguruan Tinggi Swasta di Jawa
Barat", Prosiding Seminar Nasional Multi Disiplin Ilmu.

[14]. Singh, A., Singh, S., 2016. "Impact of Promotional Tools on Students Decision Making: Study of Private Engineering Institutions in Delhi NCR", Asia Pacific Journal of Research, Vol I issue XXXV, 118-128. 